\title{
Signal Transduction from the Extracellular Matrix
}

\author{
R. L. Juliano* and S. Haskill ${ }^{\ddagger}$ \\ * Department of Pharmacology, and $\ddagger$ Lineberger Comprehensive Cancer Center, Department of Obstetrics and Gynecology, \\ and Department of Microbiology and Immunology, University of North Carolina School of Medicine, Chapel Hill, \\ North Carolina 27599
}

\section{The Role of Extracellular Matrix in the Control of Cell Differentiation}

Adhesive interactions between cells and the insoluble meshwork of extracellular matrix proteins play a vital role in embryonic morphogenesis $(33,36,94,109,135,145)$, and in the regulation of gene expression in cells of the adult organism $(1,6,105,124)$. While the overall phenomenology of extracellular matrix (ECM) ${ }^{1}$ effects on cell differentiation is well known, the biochemical and molecular bases for these effects have remained elusive. It is clear that many of the interactions between cells and the ECM are mediated by the integrin family of cell surface receptors $(2,3,13,72)$. However, the precise mechanism(s) whereby signals from ECM proteins are transduced via integrins to the intracellular machinery that controls cell growth, behavior, and differentiation, remains poorly defined.

There are many compelling examples of control of cell differentiation and gene expression through adhesive interactions with extracellular matrix. In fibroblasts, cell attachment has been reported to rapidly increase expression of c-fos and pro $\alpha 1(1)$ collagen messages $(26,27)$. Adhesion to fibronectin fragments, or cross-linking of the integrin $\alpha 5 / \beta 1$ fibronectin receptor with antibody, induced the expression of metalloprotease genes in fibroblastic cells; interestingly, intact fibronectin did not provoke this response nor did fibronectin fragments in solution (137). In a somewhat similar vein, stimulation of the $\alpha_{v} / \beta 3$ integrin in melanoma cells induced the expression of type IV collagenase and increased the invasive ability of these cells (115). The capacity of breast epithelial cells to express milk proteins in response to hormonal stimuli is quite dependent on the presence of an appropriate ECM (124). Studies in this system have led to the preliminary identification of matrix-dependent elements in the promoter region of the $\beta$ casein gene (111). In the immune system, activation of T-lymphocytes through the T-cell antigen receptor is markedly enhanced by integrin-mediated adhesion to fibronectin or laminin $(85,97,119)$. This process is part of a complex dialogue involving adhesive receptors occurring between mature T-cells and antigen presenting cells, as well as during lymphocyte differentiation (40, $132,133)$. There is extensive signaling "cross talk" between

1. Abbreviations used in this paper: ECM, extracellular matrix; fak, focal adhesion kinase; IE, immediate-early; MAD, monocyte adherence; PKA, cyclic nucleotide-dependent protein kinase; PKC, protein kinase C; RTK, receptor tyrosine kinases; VLA, very late antigen. the T-cell receptor, integrins, and other adhesion molecules such as CD8, with both tyrosine kinases and polyphosphoinositide hydrolysis being involved in these processes (98a). Many other examples of matrix- or adhesion-induced changes in cell differentiation and/or gene expression have been observed in a variety of cell types, including peritoneal macrophages (130), pheochromocytoma cells (81), endothelial cells (47), bone cells $(22,136)$, cultured hepatocytes $(17$, 29), and myoblasts (88). However, perhaps the most dramatic example of gene induction through adhesive interactions with matrix occurs in monocytes. These cells undergo a rapid and extensive change in the pattern of gene expression upon adherence to substrata coated with ECM proteins $(56,123)$. This system has allowed new insights into the relationships between matrix proteins, integrins, transcription factors, and gene regulation, and is discussed in more detail below.

\section{Integrins: Mediators of Cell-Matrix Interactions}

The integrins are a family of heterodimeric cell surface receptors; each integrin subunit has a large extracellular domain, a single membrane spanning region, and usually a short cytoplasmic domain $(32,60,87,107)$. The integrin receptor family of vertebrate cells is comprised of at least 14 distinct $\alpha$ subunits and 8 or more $\beta$ subunits that can associate in various combinations $(9,23,37,65,78,90)$. The $\alpha / \beta$ associations determine the ligand binding specificities of the integrin heterodimers for various ECM proteins, including fibronectin, laminin, and collagens. Some integrins, such as $\alpha 5 / \beta 1$, the "classic" fibronectin receptor, interact with only a single ECM protein (11). More commonly, an individual integrin will recognize several distinct ECM proteins $(18$, 104, 126). Cells often display multiple integrins capable of interacting with a particular ECM protein ligand $(3,24,60)$. In some cases two integrins that share a ligand will actually recognize different regions of the ligand molecule, as is true of the $\alpha 5 / \beta 1$ and $\alpha 4 / \beta 1$ fibronectin receptors (50), or the $\alpha 1 / \beta 1$ and $\alpha 6 / \beta 1$ laminin receptors (53); in other cases, such as $\alpha 5 / \beta 1$ and $\alpha 3 / \beta 1$, two integrins bind to the same region of the ECM protein (36).

This overlapping and apparently redundant expression of integrins seems paradoxical. However, two integrins that bind the same region of the same ligand may not necessarily serve identical functions in the cell. This suggestion is based on the fact that the cytoplasmic domains of integrin subunits, particularly those of the various $\alpha$ subunits $(126,127)$, dis- 
play highly divergent sequences, indicating that each subunit might contribute to discrete intracellular functions. In addition, it has recently been shown that several integrin $\alpha$ subunits undergo alternative splicing in a tissue-type specific and developmentally regulated manner $(61,128)$; this again suggests discrete intracellular functions for individual integrins. One interesting possibility is that various $\alpha / \beta$ combinations (and/or splicing variants) might transduce different signals from the extracellular matrix to the cell interior. Although integrins do not have characteristics that one might expect to find in a signal-generating receptor, such as kinase or phosphatase domains $(41,131)$, or sequences suitable for interaction with $G$ proteins (44), nonetheless, it is clear that integrins are capable of transducing signals from the ECM to the cell interior, and that these signals may trigger changes in gene expression.

\section{Signal Transduction by Integrins}

Currently, there are two broad views on the mechanism of integrin-mediated signaling; these may turn out to be complementary rather than mutually exclusive. One concept suggests that integrins transmit signals by organizing the cytoskeleton, thus regulating cell shape and internal cellular architecture. Integrin cytoplasmic domains do indeed interact with cytoskeletal components $(62,100)$, and sites of integrin-mediated adhesion to the ECM serve as nucleation foci for cytoskeletal assembly (14). It seems reasonable that appropriate cell shape and cytoskeletal organization might regulate the biosynthetic capabilities of the cell, and thus contribute to cell growth or differentiation $(6,66,67)$. Recently, however, an alternative paradigm for integrin-mediated signal transduction has emerged. In this view integrins are deemed to be true receptors capable of giving rise to biochemical signals within the cell.

Several reports have indicated that ligation of integrins can alter cellular patterns of tyrosine phosphorylation. We have used anti-integrin subunit antibodies, followed by treatment with second antibodies, to cluster integrins at the surface of human carcinoma cells; this process was designed to mimic the lateral association of integrins that occurs during the formation of adhesive contacts. Clustering of integrins caused enhanced tyrosine phosphorylation of a complex of proteins of $\sim 120-130 \mathrm{kD}(77)$. The increase in tyrosine phosphorylation was specific for integrins since clustering of other cell surface proteins did not cause this effect. Another group has shown that adhesion of mouse fibroblasts to substrata coated with the specific ligand fibronectin caused increased tyrosine phosphorylation of protein(s) of $\sim 120 \mathrm{kD}$; adhesion of cells to substrata coated with nonspecific ligands such as poly-Llysine failed to produce changes in tyrosine phosphorylation (52). Recently, one of the components of the $120-130-\mathrm{kD}$ tyrosine-phosphorylated complex in human carcinoma cells has been shown to react with antibodies to a $125-\mathrm{kD}$ protein $(77,77 \mathrm{a})$; this protein had been previously identified as a substrate for src family tyrosine kinases (73). Integrinstimulated tyrosine phosphorylation of the $125-\mathrm{kD}$ protein has also been observed in mouse fibroblasts (52). When cells were allowed to spread on fibronectin, the $125-\mathrm{kD}$ protein accumulated in focal adhesive contacts $(54,77 \mathrm{a}, 110)$. Cloning and sequencing of the $125-\mathrm{kD}$ protein has revealed that this molecule is a novel tyrosine kinase; both chicken (110) and mouse (54) forms have been independently described.
Based on its focal contact localization, the $125-\mathrm{kD}$ protein has been termed "pp125 Focal Adhesion Kinase" (ppl25 fak) (110). The primary structure of ppl25 fak indicates that it contains a clearly recognizable tyrosine kinase catalytic domain; however, this molecule has several features which set it apart from other members of the tyrosine kinase family. First, the catalytic domain is flanked by large $\mathrm{NH}_{2}$ - and $\mathrm{COOH}$-terminal domains of unknown function. Second, pp125 fak seems to be purely a cytoplasmic kinase since it lacks a transmembrane domain or any obvious sites for conjugation of lipid anchors. Third, pp125 fak lacks the SH2 and SH3 domains that are usually found in cytoplasmic tyrosine kinases as well as in other proteins known to interact with growth factor receptors $(54,76,110)$.

Observations in platelets also suggest a role for integrins in tyrosine kinase-mediated signal transduction. Agonists that trigger platelet aggregation produce a wave of tyrosine phosphorylation in these cells that affects several different sets of proteins in sequence. The pattern of agonist-induced tyrosine phosphorylation is markedly altered when specific ligands are bound to glycoprotein IIb/IIIa, a major platelet integrin $(39,45)$. Recently, a strong correlation has been demonstrated between ligation of platelet integrins and activation of ppl25 fak $(82 \mathrm{a})$; e.g., in IIb/IIIa deficient platelets from Glanzman's thrombosthenia patients, stimulation of ppl25 fak is markedly reduced. Thus, in at least three cell systems (carcinoma cells, fibroblasts, and platelets), ligation of integrins followed by integrin clustering and cytoskeletal reorganization can affect ppl25 $5^{\text {fak }}$, a novel cytoplasmic tyrosine kinase, leading to activation and increased tyrosine phosphorylation of this protein. Thus it seems likely that integrin-mediated activation of pp125 fak is an early step in a signal transduction cascade that permits the flow of information from the extracellular matrix to the cell interior.

At first glance it seems surprising that $\beta 1$ or $\beta 3$ integrins, with their short cytoplasmic domains, could induce the activation of a cytoplasmic kinase such as fak. However, there is ample precedent for this from studies of surface receptors that interact with $s r c$ kinases. Members of this family of cytoplasmic tyrosine kinases (101) are bound to the membrane by lipid anchors and are thus well positioned to interact with membrane receptors. A number of receptors with relatively short cytoplasmic domains including CD4, CD8, and T-cell receptor in lymphocytes $(108,134,142)$, GPIV in platelets (63), and IgE receptor in mast cells (35), each interact with src family members. Since ppl25 fak is known to be a substrate for src family kinases $(51,73)$, it is tempting to postulate that an interplay of $s r c$ and pp125 fak may be directly involved in integrin mediated signal transduction; however, there is currently no direct evidence to support this possibility.

One should keep in mind that signaling processes in cells are complex, and in addition to changes in tyrosine phosphorylation, a number of other integrin-related signaling events have been described. Thus in platelets there is evidence that integrin ligation can affect calcium activated proteases (4la), the $\mathrm{Na}^{+} / \mathrm{H}^{+}$antiporter (5a), and the sub-cellular distribution of phosphoinositide-3-kinase (144), as well as influencing tyrosine phosphorylation. Osteopontin and related peptides can induce calcium transients in osteoclasts via the $\alpha v / \beta 3$ integrin (89), while both cAMP (92) and calcium (95) are affected by $\beta 2$ integrin-mediated events in neutrophils. In addition, signaling events involving arachidonic 
acid metabolites have been associated with integrin-dependent cell adhesion $(19 b, 82 b)$. The relationship of these additional processes to integrin-mediated tyrosine phosphorylation is unclear at this time.

At this point, the existence of an integrin-mediated signal transduction pathway involving pp125 $15^{\text {fak }}$ seems quite evident. What is less certain, however, is the role of this pathway in the overall economy of the cell. One possibility is that activation of pp125 fak is related to anchorage dependence of cell growth (51); another is that this kinase regulates the cytoskeleton (14a). An intriguing possibility is that integrin signaling and activation of pp125 ark are related to control of gene expression and cell differentiation. This possibility is discussed in more detail in the next section, in the context of gene expression in monocytes.

\section{Integrin-mediated Gene Induction in Monocytes}

The monocyte has proven to be a valuable system for the study of integrin regulation of gene expression. From a teleological perspective, it makes good sense that cell-matrix interactions might trigger change in gene expression in these cells. To extravasate into sites of tissue injury, infection, and tissue remodeling, monocytes must adhere to and migrate over the surface of vascular and connective tissue cells and the ECM. Leukocytes migrate between damaged endothelial cells using LFA-1/ICAM and/or VLA-4/VCAM interactions and may subsequently invade through the basement membrane and into the connective tissue with the aid of the appropriate members of the VLA $(\beta 1)$ integrins $(15,99)$.

Monocytes may then embark on their critical role in host defense and tissue repair functions, primed by the receptormediated interactions experienced during their migration. Monocytes isolated by density fractionation methods express few genes associated with inflammation or growth control $(56,123)$. After adherence to plastic, an impressive number of genes associated with the inflammatory response are expressed. High steady-state levels of transcripts for IL-1b, for example, appear in $<30 \mathrm{~min}$ accounting for $\sim 0.1 \%$ of the total mRNA of the cell (123). While many of these immediate-early (IE) response genes encode cytokines, other genes encode transcription-associated proteins, such as c-fos (56), c-jun (118), I $k$ B (58), and MAD-6/A20 (123). Adhesion does not result in a global activation of gene expression in monocytes. Several constitutively expressed genes such as HLA.DR and $\beta$-actin are apparently unaffected by adhesive events while others such as the CSF-1 receptor c-fms, lysozyme, and CD-4 are rapidly downregulated by adherence (34). Gene induction requires adhesion, as parallel cultures of monocytes maintained in polypropylene tubes under constant rolling conditions fail to show priming unless low levels of endotoxin (LPS), or a phorbolester (PMA) are provided. LPS stimulation appears to mimic all of the adhesion responses while PMA stimulation is somewhat more selective $(34,123)$. Although adherence to plastic is sufficient for expression of many cytokine messages, it is not sufficient for translation or secretion (56 and S. Haskill, unpublished observations) without exposure to a second activation signal such as that provided by LPS.

Adhesion to Different ECM Components Results in Selective Patterns of Gene Expression. A series of novel monocyte adherence (MAD) cDNA clones were obtained by subtractive cDNA screening of a $\lambda$ gt10 library from 30 -min adhered monocytes (123). The MAD clones represented transcription-associated factors, including I $\kappa$ B (MAD-3) the inhibitor/sequestration factor for NK- $\kappa \mathrm{B}$ (58), MAD6/A20 a zinc finger apparent transcription factor that inhibits apoptosis $(98,123)$, as well as several cytokines, GRO $\beta$ and GRO $\gamma$ (MAD-2) (57), and a novel version of the IL-1ra (MAD-15) (59). In addition, a superoxide dismutase (SOD), an inducible prostaglandin synthetase, IL-8, and MIP-1b were identified subsequently. While adhesion to plastic is clearly responsible for a broad pattern of activation of monocyte mediators of inflammation and host defense, it seems likely that this is not representative of the selective gene activation events which occur in vivo. The ECM has a profound selective influence on monocyte priming events. Adhesion to fibronectin-coated plastic regulates expression of several monocyte cytokine genes in a pattern that is distinct from adhesion to type IV collagen, while laminin-coated surfaces appear to be relatively inefficient as a stimulus to monocyte gene expression $(34,123)$. For example, MAD-5, 6, and 7 all are specifically induced by adhesion to type IV collagen whereas, MAD-15 (IL-1ra) and CSF-1 show specificity for fibronectin coated surfaces. Other genes such as GRO, IL-1 and IL-8 are induced on all surfaces.

Gene Induction Via $\beta 1$ but not $\beta 2$ Integrin Engagement. Monoclonal antibody cross-linking of the $\beta 2$ integrins (antiCD18) failed to induce transcripts for any of the IE genes, although similar treatment of neutrophils has previously been shown to mediate adherence-dependent $\mathrm{H}_{2} \mathrm{O}_{2}$ production $(7,93,117)$, and regulation of calcium and cAMP levels in neutrophils $(92,95)$. In contrast, receptor cross-linking of the common $\beta 1$ chain of the very late activation antigen (VLA) family resulted in the rapid accumulation of transcripts for all the genes induced by adherence (143). In attempting to show that specific integrin signaling would result in selective gene expression, nonadherent monocytes were stimulated with a panel of antibodies to the $\alpha 4$ subunit. Once again a pattern of gene induction suggestive of nonselective activation. Integrin cross-linking and not Fc receptor engagement was required as shown by the effectiveness of (Fab) 2 antibodies and the lack of stimulation of the monovalent Fab fragment. It thus appears that specificity of gene expression does not reside in integrin engagement alone, but may require adhesion, shape change, and cytoskeletal rearrangements, or receptor recognition of distinct ligand domains.

Translocation of NF-kB May be a Sufficient Stimulus for Integrin and Adhesion Regulated IE Gene Expression. Specific transcription factors are known to be necessary or sufficient for in vitro and in vivo expression of many of the genes in question. Table I summarizes the transcriptional elements which are thought to be involved in regulation of these genes. Most, if not all, of these genes have also been shown to be inducible in other cells via IL-1, TNF $\alpha$, LPS, PMA, cAMP, or calcium ionophore activation pathways presumably involving PKCs or PKA (for example see 4, 5, $43,116,120,141$ ). However, specific protein kinasemediated pathways only partially control the activation of known transcription factors (112). Examination of Table I indicates that two sequence features are commonly associated with IE genes induced by adhesion. All contain repetitive AU rich sequences which regulate mRNA stability and translational efficiency (79). In addition, the NF-kB transcription motif is found in all of the IE genes. These transcription ele- 


\begin{tabular}{|c|c|c|c|c|c|c|}
\hline & \multicolumn{5}{|c|}{$5^{7}$ Enhancer elements } & \multirow{2}{*}{$\begin{array}{c}\begin{array}{c}\text { mRNA stability } \\
\text { element }\end{array} \\
\text { AUUUA }\end{array}$} \\
\hline & $N F-k B$ & AP-1 & CRE & c-myb & HLH & \\
\hline \multicolumn{7}{|l|}{ Upregulated IE Genes } \\
\hline IL-1b (20) & + & $?$ & + & + & + & + \\
\hline $\operatorname{TNF} \alpha(125,21,30)$ & + & + & - & + & - & + \\
\hline IL-8 (91) & + & + & + & + & - & + \\
\hline MAD 6/A20 (98) & + & $?$ & $?$ & $?$ & $?$ & + \\
\hline GRO $\alpha(5,57)$ & + & - & - & - & - & + \\
\hline$\beta$ & + & - & + & - & - & + \\
\hline$\gamma$ & + & - & + & - & - & + \\
\hline \multicolumn{7}{|l|}{ Downregulated } \\
\hline$c$-fms (106) & - & - & & + & + & + \\
\hline lysozyme $(103,83)$ & - & - & & + & + & - \\
\hline$C D-4(121)$ & - & - & & + & + & - \\
\hline
\end{tabular}

Summary of the reported and author (S. Haskill) identified enhancer elements present in a series of IE genes upregulated by adherence. Enhancer motifs present in three genes downregulated by adherence are also presented. The presence of a particular element has been functionally identified for only a few cases; otherwise elements have been noted by sequence inspection.

ments are absent in promoters of genes which are downregulated by adherence. In contrast, these genes appear to be regulated by a different pattern of elements including $c$-myb and helix-loop-helix (HLH) proteins. Translocation of enhanced levels of NF- $\kappa$ B from a cytoplasmic site of sequestration by $I \kappa B$ into the nucleus is known to occur after adhesion of human monocytes (48). Thus we hypothesize that adhesion and/or integrin-dependent kinase events are sufficient for nuclear translocation of NF- $\kappa \mathrm{B}$, leading to induction of IE genes. Conversely, adhesion may inhibit the continued nuclear localization of c-myb and HLH transcription factors leading to downregulation of this class of gene. The very robust integrin mediated response in monocytes has allowed gene expression in this system to be analyzed in some detail. It seems reasonable to suspect that matrix or adhesionmediated gene induction events in other systems, such as epithelial cells (111) or fibroblasts $(26,27)$, may also exhibit considerable selectivity, and that this may be related to the activation of specific transcription factors by individual matrix components.

\section{Parallels to Growth Factor Receptor Signaling Pathways}

As integrin-mediated signal transduction pathways begin to be defined, it may be worthwhile to briefly consider whether they might resemble the better studied pathways of growth factor-mediated signaling. Many polypeptide growth factors, including insulin, EGF and PDGF, bind to cell surface receptor tyrosine kinases (RTKs) (131). Binding of the ligand usually causes receptor dimerization, activates the latent tyrosine kinase, and sets up a complex signal transduction cascade. The RTKs have a number of key intracellular targets that are participants in this cascade (see 8,16, 19, 74 and references therein). This would include phospholipase $C$ gamma (PLC $\gamma$ ) (96) which cleaves membrane phosphoinositides to yield diacyl glycerol as well as inositol 1,4,5 triphosphate. Another RTK target is ras GTPase Activating Protein (rasGAP) which plays a vital role in controlling the signaling activity of ras proteins $(16,25)$. Phosphoinositide3-kinase (PI-3-K) an enzyme that influences actin filament assembly (16) is also a target. RTKs also induce the tyrosine phosphorylation and activation of key intracellular serine/ threonine kinases including Raf-1 $(80,82)$, and the 42-44$\mathrm{kD}$ kinases termed ERKs or MAP kinases $(10,129)$. Recent observations have suggested that ras proteins may act "down"stream" of RTKs but "upstream" of events leading directly to activation of MAP kinases and of Raf-1 (138).

These complex observations have led to the suggestion that RTKs physically organize multiple proteins involved in signal transduction (131). PLC $\gamma$, ras GAP, PI-3-K, as well as $s n c$-family tyrosine kinases, all posses homologous domains (SH2 domains) that can promote the association of these proteins with activated RTKs (76), thus giving support to the concept of a "signal transduction complex." In addition, there is a substantial amount of cross talk between the potential signaling pathways sketched out above. Thus phospholipase Cs can also be activated via G-protein coupled receptors (16), subsequently activating protein kinase $C$. In turn, protein kinase $\mathrm{C}$ can modulate the activity of some RTKs directly, as well as having an effect on ras GAP function (16). Cytoplasmic tyrosine kinases, including those of the src family, can also impinge on these signaling pathways (38). While many important details remain unclear, a picture emerges of parallel and intersecting signal transduction pathways for RTKs, with a considerable degree of redundancy and overlap. Ultimately, the complex cytoplasmic signaling cascades converge on the nucleus, leading to changes in cell growth or differentiation. Phosphorylation is a common currency for many of these transactions. Thus, a number of transcription factors seem to be directly regulated by ser/threonine kinases and phosphatases (64). For example, I $\mathrm{BB}$ the inhibitory subunit of NF- $\kappa B$ apparently is a substrate for protein kinase $\mathrm{C}$ and protein kinase $\mathrm{A}$ (see below); I $\mathrm{B}$ also has a consensus sequence for binding of the PI-3-K (58). The CREB transcription factor is activated by cAMP dependent protein kinase, while members of the AP-1 group of transcription factors are regulated by PKC, and by MAP kinases and Raf-1 kinase $(16,71,74)$. Tumor suppressor gene products such as p105-RB are also regulated by phosphorylation (84). Finally, protein kinases and phosphatases play a critical role in cell cycle control $(31,64 a)$. A highly simplified 


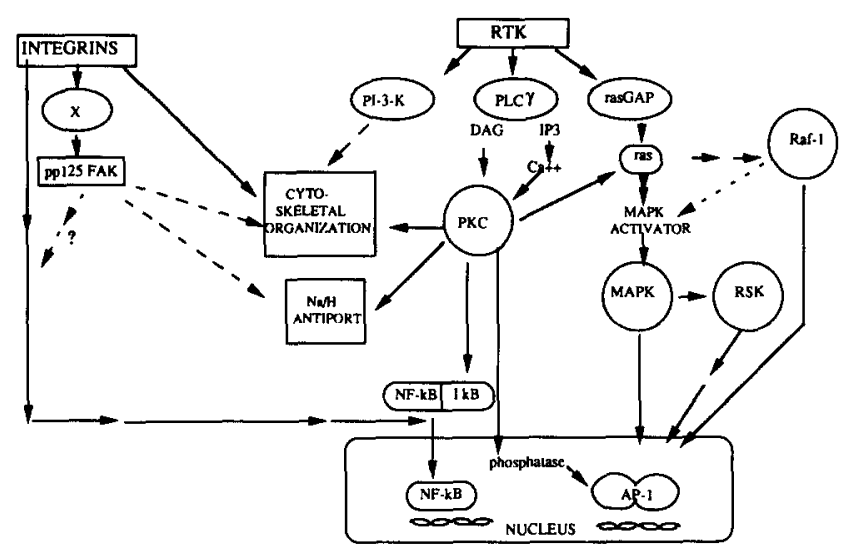

Figure 1. Signaling pathways mediated by receptor tyrosine kinases versus integrin mediated pathways. The left hand section of the figure shows the tentative pathways of integrin-mediated signal transduction. The right hand section of the figure shows the better established pathways for RTK signal transduction (adapted from references $16,74,80,138$ ). Solid arrows indicate connections which are reasonably well established, while dotted arrows indicate more tentative connections, and question marks indicate purely hypothetical connections. Additional arrowheads along a path indicate the existence of multiple steps rather than a direct interaction. All aspects of the integrin-mediated pathways should be regarded as being based on tentative information at this point. Initial targets of RTKs or integrins are shown as ovals. Ser/threo kinases are shown as circles. Preliminary data using kinase inhibitors suggests that PKC is not part of the main pathway of integrin-mediated gene induction (Yurochko, A., and S. Haskill, unpublished observations). $R T K$, receptor tyrosine kinase; ppl25kak, the integrinregulated $125-\mathrm{kD}$ focal adhesion kinase; $P I-3-K$, phosphatidylinositol-3-kinase; $P L C \gamma$, phospholipase $\mathrm{C}$ gamma; rasGAP, ras GTPase activating protein; Raf-1, the protein kinase product of c-raf; $P K C$, protein kinase $\mathrm{C} ; M A P K$, microtubule associated protein ser/threo kinases, also known as ERKs; $R S K$, ser/threo kinases also known as S6 kinases; $N F-k B / l k B$, the NF- $k B$ transcription factor and its cytoplasmic inhibitor protein; AP-1, the AP-1 (fos/jun) transcriptional regulatory complex; DAG, diacylglycerol; and IP3, phosphatidyl inositol $1,4,5$ triphosphate.

version of the RTK signaling cascade is shown in Fig. 1. A major question will be whether events triggered by integrins will turn out to intersect with RTK triggered pathways. If that were the case, a second question is whether integrin-mediated signals would enhance or diminish the growth promoting effects of RTK activation.

\section{Issues and Unknowns}

Signal transduction from the ECM and its relationship to the control of gene expression is an exciting new area for investigation; at this juncture, however, there are clearly more questions than answers. Some of the potentially important issues for this field are delineated below.

Mechanisms of Interaction of Integrins and pp125jak. There are many unresolved issues concerning the mechanism whereby integrin ligation stimulates $\mathrm{pp} 125^{\text {alk }}$. A variety of integrins can influence pp125 $\beta 1, \alpha 5 / \beta 1, \alpha 2 / \beta 1$, and $\alpha \Pi b / \beta 3$ all seem to be effective (45, 77; 82a); Bauer, J. S., J. Varner, C. Schreiner, L. Kornberg, R. Nicholas and R. L. Juliano, manuscript submitted for publication). A related issue concerns the relative contribu- tion of the $\alpha$ and $\beta$ subunits to ppl25 $25^{\text {fik }}$ activation, with one report suggesting that truncation of the $\beta$ subunit abolishes integrin-mediated tyrosine phosphorylation (52), while studies on the role of the $\alpha 5$ subunit suggest that truncation of the cycloplasmic domain does not compromise tyrosine phosphorylation (Bauer, J. S., J. Varner, C. Schreiner, L. Kornberg, R. Nicholas, and R. L. Juliano, manuscript submitted for publication). It may also be premature to conclude that the interactions between integrins and $\mathrm{ppl} 25^{\text {fak }}$ are mediated solely through cytoplasmic domains. An intriguing possibility is that integrins may interact, via their transmembrane or extracellular regions, with other membrane proteins, such as the $50-\mathrm{kD}$ integrin-associated protein (12), or the CD9 antigen (122), which might then interact with the tyrosine phosphorylation signaling system. The exact mechanism of integrin-enhanced tyrosine phosphorylation of pp125 $5^{\text {fik }}$ is also unclear. It is possible that a physical interaction with integrins, with other membrane proteins, or with cytoskeletal components, directly activates pp125 $5^{\text {ank }}$, which then autophosphorylates itself. Alternatively, stimulation through integrins may initially activate another kinase (or inactivate a phosphatase) that acts on pp125 fik. Finally, stimulation through integrins may simply bring $\mathrm{pp} 125^{\text {ink }}$ and another kinase into closer juxtaposition thus allowing the unknown kinase to phosphorylate and activate pp125 iak. Several lines of evidence suggest that integrin-induced organization of the cytoskeleton may be associated with activation of $\mathrm{pp1} 25^{\text {fak }}$. Thus, cytochalasin D treatment, which disrupts actin filament organization, can block tyrosine phosphorylation of pp125 (ak (82a). Integrin-mediated cell adhesion also induces tyrosine phosphorylation of paxillin, an important cytoskeletal protein, while tyrosine kinase inhibitors partially block cytoskeletal assembly (14a). Both of these observations suggest that activation of pp125 may represent one step in the complex, multi-step process of cytoskeletal assembly. Since protein kinase $\mathrm{C}$ isoforms (70) have also been implicated in cytoskeletal assembly, study of the interplay between PKC and ppl25 $5^{\text {ak }}$ will likely be of interest.

Possible Downstream Events. The mechanistic connections between integrin clustering or cell adhesion, subsequent activation of pp125 tak , and events downstream of pp125 fak, remain almost totally unknown. One event which may be downstream of integrin-mediated tyrosine phosphorylation is cytoplasmic alkalinization effected through the $\mathrm{Na}^{+} / \mathrm{H}^{+}$antiporter. Initial observations suggested that cytoplasmic $\mathrm{pH}$ went up when cells attached and spread on fibronectin (68); more recently, it has been shown that cell spreading is not required, and that clustering of integrins caused by antibodies or by aggregated fibronectin is sufficient (113, 114). This is strikingly parallel to observations on integrinmediated tyrosine phosphorylation (77). In growth factor signaling pathways, activation of the $\mathrm{Na}^{+} / \mathrm{H}^{+}$antiporter is thought to be downstream from initial activation of RTKs, and mediated through protein kinase $C(16,49)$; perhaps the same relationship holds in integrin-mediated signaling pathways.

Transcription Specificity in Cell Adhesion Must Be Determined by Multiple Promoter Elements. All of the IE response genes induced by adhesion of monocytes, or by stimulation of $\beta 1$ integrins, share the NF- $k B$ transcriptional motif (Table I). Since I $k B$, the cytoplasmic inhibitory factor for $\mathrm{NF}-k \mathrm{~B}$, is reported to be a substrate for protein kinase C 

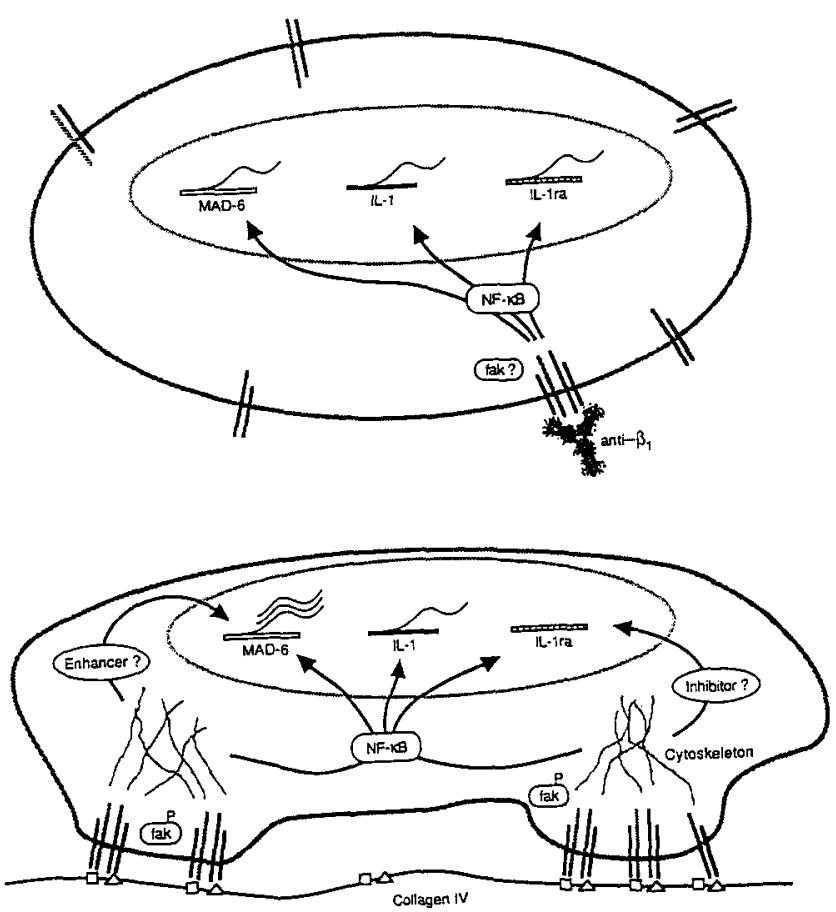

Figure 2. Three signal model of matrix-induced gene expression. Both positive and negative regulation of transcription seems to be required to account for the specificity of matrix-induced gene expression. The upper panel shows a general signal resulting from antibody ligation of betal integrins on nonadhered cells; adhesion to nonphysiological substrata (plastic) produces a similar result. The lower panel shows both positive and negative signals generated by adhesion to a natural matrix ligand in this case type IV collagen. Integrins interacting with both the NC-1 ( $\square$ ) (non-collagenous domain) and PIV $(\Delta)$ (peptide IV of the triple helical domain; 19a) binding sites in type IV collagen are shown. The focal adhesion tyrosine kinase pp125 fak is indicated as a possible participant in the signaling process.

(43), this indicates one possible mechanism for regulation on these IE genes is through phosphorylation of $\mathrm{I} k \mathrm{~B}$ leading to nuclear translocation of NF- $k \mathrm{~B}$. Regulation of gene expression is clearly more complicated than the simplistic view of a single transcription factor binding in an on/off fashion to a specific promoter sequence. Both positive and negative cooperation between induced and constitutive factors may be involved in gene regulation $(69,91)$. In addition, the same enhancer element (AP-1, for example) may be the site of both positive and negative regulation $(28,75)$. Although the nuclear translocation of NF- $k \mathrm{~B}$ is associated with adhesion to plastic (48), adherence to ECM ligands that provide specificity of gene induction is likely to induce the nuclear association of additional positive and/or negative transcription factors, not seen through direct integrin engagement or adhesion to plastic. For example, engagement of VLA-5 on lymphocytes activates the AP-1 transcription complex of fos/jun proteins $(140)$, as does adhesion to plastic $(56,118)$. Thus, at least two distinct enhancer elements, NF- $k$ B and AP-1, are likely to be activated by adhesion to ECM. The enhanced transcripts of MAD-6/A20 seen on adhesion of monocytes to type IV collagen, and the lack of IL-lra transcripts might simply be explained by the lack of a positive stimulus in the later case. However, since several other genes such as IL-1 are induced regardless of the ECM surface (143), this suggests that the genes which show matrix selectivity do so because of the contributions of negative and positive transcription factors, and not simply due to the failure to induce transcription. This scenario suggests the existence of at least two additional signals regulating monocyte gene expression in response to cell adhesion to the ECM (see Fig. 2). A general signal might always result from the ligation of integrins, whether by antibodies or through cell adhesion; this signal would ultimately impinge on NF- $k B$, leading to activation of a large number of IE genes. More specific signals might result from interactions of integrins with their natural ECM ligands; these signals would impinge on both positive and negative transcription factors that are selective for sub-sets of the IE genes. A model of the type shown in Fig. 2, with both positive and negative signaling pathways, would be consistent with the data accumulated on adherence related gene induction in monocytes, as well as with many other observations in the literature on the complex process of matrixinduced gene expression.

Relationship Between Integrin-mediated Tyrosine Phosphorylation and Induction of Gene Expression. Integrindependent adhesive interactions with ECM proteins, as well as stimulation of integrins with antibodies, can lead to the induction of new gene expression. Similar events also lead to integrin mediated changes in tyrosine phosphorylation, particularly activation of pp $125^{\text {ank }}$. Thus, it is tempting to place the increased tyrosine kinase activity of $\mathrm{pp} 125^{\text {fak }}$ in a cause and effect relationship with integrin-induced gene expression. However, it is probably wise to proceed cautiously in making these interpretations. At this point there is simply no direct evidence that would implicate pp125 $25^{\text {fik }}$ activation in a causal manner with integrin induced gene expression. Since ppl25 is is tyrosine phosphorylated rather promiscuously in response to integrin clustering or cell adhesion, it seems unlikely that activation of this kinase controls the specific patterns of gene induction triggered by different ECM ligands. Rather, it seems more likely that ppl $25^{\text {tak }}$ may be part of the general activating signal in the transcriptional pathways described in Fig. 2 above. This would suggest the existence of additional integrin-mediated signaling pathways, so as to explain the observation that different ECM proteins can induce unique patterns of gene expression. Alternatively, specificity might reside in selection of alternate substrates for $\mathrm{pp} 125^{\text {fak }}$ when different integrins are stimulated.

Received for publication 10 August 1992 and in revised form 29 October 1992.

Note Added in Proof. A recent report has indicated that stimulation of G protein linked neuropeptide receptors can increase tyrosine phosphorylation of pp125 fak (Zachary, I., J. Sinnett-Smith, and E. Rozengurt. 1992. J. Biol. Chem. 267:19031-19034).

\section{References}

1. Adams, J. C., and F. M. Watt. 1989. Fibronectin inhibits the terminal differentiation of human keratinocytes. Nature (Lond.). 340:307-309.

2. Akiyama, S. K., K. Nagata, and K. Yamada. 1990. Cell surface receptors for extracellular matrix components. Biochim. Biophys. Acta. 1031: 91-110

3. Albelda, S. M., and C. A. Buck. 1990. Integrins and other cell adhesion molecules. FASEB (Fed. Am. Soc. Exp. Biol.) J. 4:2868-2880.

4. Angel, P., M. Imagawa, R. Chiu, B. Stein, R. J. Imbra, H. J. Rahmsdorf, C. Jonat, P. Herrlich, and M. Karin. 1987. Phorbol ester-inducible 
genes contain a common cis element recognized by a TPA-modulated trans-acting factor. Cell. 49:729-739.

5. Anisowicz, A., M. Messineo, S. W. Lee, and R. Sager. 1991. An NF-kBlike transcription factor mediates IL-1/TNF-a induction of $g r o$ in human fibroblasts. $J$. Immunol. 147:520-527.

5a. Banga, H. S., E. R. Simons, L. F. Brass, and S. E. Rittenhouse. 1986. Activation of phospholipases $A$ and $C$ in human platelets exposed to epinephrine: role of glycoprotein llb/llla and a dual role for epinephrine. Proc. Natl. Acad. Sci. USA. 83:9197-9201.

6. Ben-Ze-ev, A., G. S. Robinson, N. L. R. Bucher, and S. R. Farmer, 1988. Cell-cell and cell-matrix interactions differentially regulate the expression of hepatic and cytoskeletal genes in primary cultures of hepatocytes. Proc. Natl. Acad. Sci. USA. 85:2161-2165.

7. Berton, G., C. Laudanna, C. Sorio, and F. Rossi. 1992. Generation of signals activating neutrophil functions by leukocyte integrins: LFA-1 and gp150/95, but not CR3, are able to stimulate the respiratory burst of human neutrophils. J. Cell Biol. 116:1007-1017.

8. Bishop, J. M. 1991. Molecular themes in oncogenesis. Cell. 64:235-248.

9. Bossy, B. E. Bossy-Wetzel, and L. F. Reichardt. 1991. Characterization of the integrin alpha8 subunit: a new betal associated subunit which is prominently expressed on axons and on cells in contact with basal lamina in chick embryos. EMBO (Eur. Mol. Biol. Organ.) J. 10:2375-2385.

10. Boulton, T. G S. H. Nye, D. J. Robbins, N Y Ip, E Radziejewska, S. D. Morgenbesser, R. A. DePinho, N. Panayotatos, M. H. Cobb, and G. D. Yancopoulos. 1991. ERKs: a family of protein serine/threonine kinases that are activated and tyrosine phosphorylated in response to insulin and NGF. Cell. 65:663-675.

11. Brown, P. J., and R. L. Juliano. 1985. Selective inhibition of fibronectinmediated adhesion by monoclonal antibodies to a cell surface glycoprotein. Science (Wash. DC). 228:1448-1451.

12. Brown, E., L. Hooper, T. Ho, and H. Gresham. 1990. Integrin associated protein: a $50 \mathrm{kD}$ plasma membrane antigen physically and functionally associated with integrins. J. Cell. Biol. 111:2785-2794.

13. Buck, C. A., and A. F. Horwitz. 1987. Cell surface receptors for extracellular matrix molecules. Annu. Rev. Cell Biol. 3:179-205.

14. Burridge, K., K. Fath, T. Kelley, G. Nuckolls, and C. Turner. 1988. Focal adhesions: transmembrane junctions between the extracellular matrix and the cytoskeleton. Annu. Rev. Cell Biol. 4:487-525.

14a. Burridge, K., C. Turner, and L. Romer. 1992. Tyrosine phosphorylation of paxillin and ppl25FAK accompanies cell adhesion to extracellular matrix: a role in cytoskeletal assembly. J. Cell Biol. 119:893-904.

15. Butcher, E. C. 1991. Leukocyte-endothelial cell recognition: three (or more) steps to specificity and diversity. Cell. 67:1033-1036.

16. Cantley, L. C., K. R. Auger, C. Carpenter, B. Duckworth, A. Graziani, R. Kapeller, and S. Soltoff. 1991. Oncogenes and signal transduction. Cell. 64:281-302

17. Caron, J. M. 1990 . Induction of albumin gene transcription in hepatocytes by extracellular matrix proteins. Mol. Cell Biol. 10:1239-1243.

18. Carter, W. G., M. C. Ryan, and P. F. Gahr. 1991. Epiligrin, a new cell adhesion ligand for integrin $\alpha 3 \beta 1$ in epithelial basement membranes. Cell. 65:599-610.

19. Chao, M. 1992. Growth factor signaling: where is the specificity? Cell. 88:995-997

19a. Chelberg, M. K., J. B. McCarthy, A. P. N. Skubitz, L. T. Furcht, and E. C. Tsilibary. 1990. Characterization of a synthetic peptide from type IV collagen that promotes melanoma cell spreading and cell motility. $J$. Cell Biol. 111:261-270.

19b. Chun, J. S., and B. S. Jacobson. 1992. Spreading of HeLa cells on a collagen substratum requires a second messenger formed by the lipoxygenase metabolism of archidonic acid released by collagen receptor clustering. Mol. Biol. of the Cell. 3:481-492.

20. Clark, B. D., K. L. Collins, M. S. Gandy, A. C. Webb, and P. E. Auron. 1986. Genomic sequence for human prointerleukin1 beta: possible evolution from a reverse transcribed prointerleukin 1 alpha gene. Nucleic Acids Res. 14:7897-7914.

21. Collart, M. A., P. Baeuerle, and P. Vassalli. 1990. Regulation of tumor necrosis factor alpha transcription in macrophages: involvement of four kB-like motifs and of constitutive and inducible forms of NF-kB. Mol. Cell. Biol. 10:1498-1506.

22. Dedhar, S. 1989. Signal transduction via the $b_{1}$ integrins is a required intermediate in interleukin-1b induction of alkaline phosphatase activity in human osteosarcoma cells. Exp. Cell. Res. 183:207-214.

23. Dedhar, S. 1991. Integrins and tumor invasion. Bioessays. 12:583-589.

24. Defilippi, P., G. Truffa, G. Stefanuto, F. Altruda, L. Silengo, and G. Tarone. 1991. Tumor necrosis factor $a$ and interferon gamma modulate the expression of the vitronectin receptor (integrin $b_{3}$ ) in human endothelial cells. J. Biol. Chem. 266:7638-7645.

25. Der, C. J. 1989. The ras family of oncogenes. In Cancer Treatment and Research. Vol 18. Oncogenes. C. Benz and E. Liu, editors. 73-119.

26. Dhawan, J., and S. R. Farmer. 1990. Regulation of alpha 1 (I)-collagen gene expression in response to cell adhesion in Swiss 3T3 fibroblasts. J. Biol. Chem. 265:9015-9021.

27. Dhawan, J., A. C. Lichtler, D. W. Rowe, and S. R. Farmer. 1991. Cell adhesion regulates pro-alpha 1(I) collagen mRNA stability and transcription in mouse fibroblasts. $J$. Biol. Chem. 266:8470-8475.
28. Diamond, M. I., J. N. Miner, S. K. Yoshinaga, and K. R. Yamamoto. 1990. Transcription factor interactions: selectors of positive or negative regulation from a single DNA element. Science. 249:1266-1272.

29. DiPersio, C. M., D. A. Jackson, and K. S. Zaret. 1991. The extracellular matrix coordinately modulates liver transcription factors and hepatocyte morphology. Mol. Cell. Biol. 11:4405-4414.

30. Drouet, C., A. N. Shakhov, and C. V. Jongeneel. 1991. Enhancers and transcription factors controlling the inducibility of the tumor necrosis factor-a promoter in primary macrophages. J. Immunol. 147:16941700.

31. Dunphy, W. G., and A. Kumagai. 1991. The cdc25 protein contains intrinsic phosphatase activity. Cell. 67:189-196.

32. Dustin, M. L., and T. A. Springer. 1991. Role of lymphocyte adhesion receptors in transient cell interactions and cell locomotion. Annu. Rev. Immunol. 9:2-66.

33. Edelman, G. M., and K. L. Crossin. 1991. Cell adhesion molecules: Implications for a molecular histology. Annu. Rev. Biochem. 60:155-190.

34. Eierman, D. F., C. E. Johnson, and J. S. Haskill. 1989. Human monocyte inflammatory mediator gene expression is selectively regulated by adherence substrates. $J$. Immunol. 142:1970-1976.

35. Eiseman, E., and J. B. Bolen. 1992. Engagement of the high affinity IgE receptor activates src protein related tyrosine kinases. Nature (Lond.). 355:78-80.

36. Elices, M. J., L. A. Urry, and M. E. Hemler. 1991. Receptor functions for the integrin VLA-3: Fibronectin, collagen, and laminin binding are differentially influenced by ARG-GLY-ASP peptide and by divalent cations. J. Cell Biol. 112:169-181.

37. Erle, D. J., C. Ruegg, D. Sheppard, and R. Pytela. 1991. Complete amino acid sequence of an integrin beta subunit(beta7) identified in leukocytes J. Biol. Chem. 266:11009-11016.

38. Ettehadieh, E., J. S. Sanghera, S. L. Pelech, D. Hesse-Bienz, J. Watts, N. Shastri, and R. Aebersold. 1992. Tyrosyl phosphorylation and activation of MAP kinases by p56lck. Science (Wash. DC) 255:853-855.

39. Ferrell, J. E., and S. Martin. 1989. Tyrosine specific protein phosphorylation is regulated by glycoprotein IIb-IIIa in platelets. Proc. Natl. Acad. Sci. USA. 86:2234-2238.

40. Fine, J. S., and A. M. Kruisbeek. 1991. The role of LFA-1/ICAM-1 interactions during murine T lymphocyte development. J. Immunol. 147 2852-2859.

41. Fischer, E. H., H. Charbonneau, and N. K. Tonks. 1991. Protein tyrosine phosphatases: a diverse family of intracellular and transmembrane enzymes. Science (Wash. DC). 253:401-406.

41a. Fox, J. E. B., D. E. Goll, C. C. Reynolds, and D. R. Phillips. 1985 Identification of two proteins (actin binding protein and P235) that are hydrolyzed by endogenous calcium dependent protease during platelet activation. J. Biol. Chem. 260:1060-1066.

42. Frederickson, R. M., M. R. Michaeu, A. Iawamoto, and N. G. Miyamoto. 1989. 5' flanking and first intron sequences of the human b-actin gene required for efficient promoter activity. Nucleic Acids Res. 17:53-269.

43. Ghosh, S., and D. Baltimore. 1990 . Activation in vitro of NF-kB by phosphorylation of its inhibitor, IkB. Nature (Lond.). 344:678-682.

44. Gilman, A. G. 1987. G Proteins: transducers of receptor generated signals. Annu. Rev. Biochem. 56:615-649.

45. Golden, A., J. S. Brugge, and S. Shattil. 1990. Role of platelet membrane glycoprotein IIb-IIIa in agonist induced tyrosine phosphorylation of platelet proteins. J. Cell Biol. 111:3117-3127.

46. Deleted in proof.

47. Grant, D. S., H. K. Kleinman, and G. R. Martin. 1990. The role of basement membranes in vascular development. Ann. NY Acad. Sci. 588 61-72.

48. Griffin, G. E., K. Leung, T. M. Folks, S. Kunkel, and G. J. Nabel. 1989 Activation of HIV gene expression during monocyte differentiation by induction of NF-kB. Nature (Lond.). 339:70-73.

49. Grinstein, S., D. Rotin, and M. J. Mason. 1989. Biochim. Biophys. Acta. 988:73-97.

50. Guan, J. L., and R. O. Hynes. 1990. Lymphoid cells recognize an alternatively spliced segment of fibronectin via the integrin receptor alpha 4/beta 1. Cell. 60:53-61.

51. Guan, J. L., and D. Shallaway. 1992. Regulation of focal adhesion associated protein tyrosine kinase by both cellular adhesion and oncogenic transformation. Nature (Lond.). 358:690-692.

52. Guan, J. L., J. E. Trevethick, and R. O. Hynes. 1991. Fibronectin/integrin interaction induces tyrosine phosphorylation of a $120 \mathrm{kD}$ protein Cell Regul. 2:951-964.

53. Hall, D. E., L. F. Reichardt, E. Crowley, B. Holley, H. Moezzi, A. Sonnenberg, and C. H. Damsky. 1990. The $\alpha 1 / \beta 1$ and $\alpha 1 / \beta 1$ integrin heterodimers mediate cell attachment to distinct sites on laminin. $J$. Cel Biol. 110:2175-2184

54. Hanks, S. K., M. B. Calalb, M. C. Harper, and S. K. Patel. 1992. Foca adhesion protein-tyrosine kinase phosphorylated in response to cel spreading on fibronectin. Proc. Natl. Acad. Sci. USA. 89:8481-8491.

55. Hartig, E., I. F. Loncarevic, M. Buscher, P. Herrlich, and H. J. Rahmsdorf 1991. A new cAMP response element in the transcribed region of the human c-fos gene. Nucleic Acids Res. 19:4153-4159. 
56. Haskill, S., C. Johnson, D. Eierman, S. Becker, and K. Warren. 1988. Adherence induces selective mRNA expression of monocyte mediators and proto-oncogenes. J. Immunol. 140:1690-1694.

57. Haskill, S., A. Peace, J. Morris, S. A. Sporn, A. Anisowicz, S. Lee, T. Smith, G. Martin, P. Ralph, and R. Sager. 1990. Identification of three related human GRO genes encoding cytokine functions. Proc. Natl. Acad. Sci. USA. 87:7732-7736.

58. Haskill, S., A. A. Beg, S. M. Tompkins, J. S. Morris, A. D. Yurochko, A. Sampson-Johannes, K. Mondal, P. Ralph, and A. S. Baldwin, Jr. 1991. Characterization of an immediate-early gene induced in adherent monocytes that encodes I kappa B-like activity. Cell. 65:1281-1289.

59. Haskill, S., G. Martin, L. Van Le, J. Morris, A. Peace, C. F. Bigler, G. J. Jaffe, C. Hammerberg, S. A. Spom, S. Fong, W. P. Arend, and P. Ralph. 1991. cDNA cloning of a novel intracellular form of the human interleukin-1 receptor antagonist associated with epithelium. Proc. Natl. Acad. Sci. USA. 88:3681-3685.

60. Hemler, M. E. 1990. VLA proteins in the integrin family: structures, functions and their role in leukocytes. Annu. Rev. Immunol. 8:365-400.

61. Hogervorst, F., I. Kuikman, A. G. van Kessel, and A. Sonnenberg. 1991. Molecular cloning of the human alpha6 subunit. Alternative splicing of alpha6 $\mathrm{mRNA}$ and chromosomal localization of the alpha6 and beta4 genes. Eur. J. Biochem. 199:425-433.

62. Horwitz, A., E. Duggan, C. Buck, M. C. Beckerle, K. Burridge. 1986 Interaction of plasma membrane fibronectin receptor with talin-a transmembrane linkage. Nature (Lond.). 320:531-533.

63. Huang, M. M., J. B. Bolen, J. W. Barnwell, S. Shattil, and J. S. Brugge. 1991. Membrane glycoprotein IV (CD36) is physically associated with the fyn, lyn, and yes protein tyrosine kinases in human platelets. Proc. Natl. Acad. Sci. USA. 88:7844-7848.

64. Hunter, T., and M. Karin. 1992. The regulation of transcription by phosphorylation. Cell. 70:375-87.

64a. Hunter, T., and J. Pines. 1991. Cyclins and cancer. Cell. 66:1071-1074.

65. Hynes, R. O. 1992. Integrins: versatility, modulation and signaling in cell adhesion, Cell 69:11-25.

66. Ingber, D. E. 1991. Control of capillary growth and differentiation by ex tracellular matrix. Use of a tensegrity (tensional integrity) mechanism for signal processing. Chest. 99 (3 Suppl):34-40.

67. Ingber, D. E., and J. Folkman. 1989. How does extracellular matrix control capillary morphogenesis? Cell. 58:803-805.

68. Ingber, D. E., D. Prusty, J. V. Frangioni, E. J. Cragoe, C. Lechene, and M. A. Schwartz. 1990. Control of intracellular pH and growth by fibronectin in capillary endothelial cells. $J$. Cell Biol. 110:1803-1811.

69. Jain, J., V. E. Valge-Archer, A. J. Sinskey, and A. Rao. 1992. The AP-1 site at $-150 \mathrm{bp}$, but not the NF-kB site, is likely to represent the major target of protein kinase $\mathrm{C}$ in the interleukin 2 promoter. $J$. Exp. Med. $175: 853-862$

70. Jaken, S., K. Leach, and T. Klauck. 1989. Association of type 3 protein kinases $\mathrm{C}$ with focal contacts in rat embryo fibroblasts. J. Cell Biol. 109:697-704.

71. Jamal, S., and E. Ziff. 1990. Transactivation of c-fos and beta actin genes by raf as a step in the early response to membrane signals. Nature (Lond.). 344:463-466.

72. Juliano, R. L. 1987. Membrane receptors for extracellular matrix macromolecules: relationship to cell adhesion and tumor metastasis. Biochim. Biophys. Acta. 907:261-268.

73. Kanner, S. B. A. B. Reynolds, R. R. Vines, and J. T. Parsons, 1990 Monoclonal antibodies to individual tyrosine kinase phosphorylated protein substrates of oncogene encoded tyrosine kinases. Proc. Natl. Acad. Sci. USA. 87:3328-3332.

74. Karin, M, 1992. Signal transduction from cell surface to nucleus in development and disease. FASEB (Fed. Am. Soc. Exp. Biol.) J, 6:2581-2590.

75. Kobierski, L. A., H. M. Chu, Y. Tan, and M. J. Comb. 1991. cAMPdependent regulation of proenkephalin by JunD and JunB: positive and negative effects of AP-1 proteins. Proc. Natl. Acad. Sci. USA. 88: $10222-10226$

76. Koch, C. A., D. Anderson, M. F. Moran, C. Ellis, and T. Pawson. 1991 SH2 and SH3 domains: elements that control interactions of cytoplasmic signaling proteins. Science (Wash. DC). 252:668-674.

77. Kornberg, L., H. S. Earp, C. Turner, C. Prokop, and R. L. Juliano. 1991 Signal transduction by integrins: increased protein tyrosine phosphorylation caused by clustering of betal integrins. Proc. Natl. Acad. Sci. USA. 88:8392-8396.

77a. Kornberg, L. , H. S. Earp, J. T. Parsons, M. Schaller, and R. L. Juliano, 1992. Cell adhesion of integrin clustering increases phosphorylation of a focal adhesion associated tyrosine kinase. J. Biol. Chem. 267 $23439-23442$.

78. Kramer, R. H., M. P. Vu, Y. F. Cheng, D. M. Ramos, R. Timpl, and N. Waleh. 1991. Laminin binding integrin alpha7/betal: functional characteristics and expression in normal and malignant melanocytes. Cell. Regul. 2:805-817.

79. Kruys, V., O. Marinx, G. Shaw, J. Deschamps, and G. Huez, 1989. Translational blockade imposed by cytokine-derived UA-rich sequences. Science. 245:852-855.

80. Krykakis, J. M., H. App, X. F. Zhang, P. Banerjee, D. L. Brautigan, U. R. Rapp, and J. Avruch. 1992. Raf-1 activates MAP kinase-kinase.
Nature (Lond.) 358:417-21

81. Kubota, S., K. Tashiro, and Y. Yamada. 1992. Signaling site of laminin with mitogenic activity. J. Biol. Chem. 267:4285-4288.

82. Li, P., K. Wood, H. Mamon, W. Haser, and T. Roberts. 1991. Raf-1 a kinase currently without a cause but not lacking in effects. Cell. 64: $479-482$.

82a. Lipfert, L., B. Haimovich, M. D. Schaller, B. S. Cobb, J. T. Parsons, and J. S. Brugge. 1992. Integrin-dependent phosphorylation and activation of the protein kinase pp125 ink in platelets. J. Cell Biol. 119:905-912.

82b. Liu, B., J. Timar, J. Howlett, C. A. Diglio, and K. V. Honn. 1991. Lipoxygenase metabolites of arachidonic and linoleic acids modulate the adhesion of tumor cells to endothelium via regulation of protein kinase C. Cell Regul. 2:1045-1055.

83. Luckow, B., and G. Schutz. 1989. Cell-type specificity of regulatory elements identified by linker scanning mutagenesis in the promoter of the chicken lysozyme gene. Nucleic Acids Res. 17:8451-8462.

84. Marshall, C. J. 1991. Tumor suppressor genes. Cell. 64:331-326.

85. Matsuyama, T., A. Yamada, J. Kay, K. M. Yamada, S. K. Akiyama, S. F. Schlossman, and C. Morimoto. 1989. Activation of CD4 cells by fibronectin and anti-CD3 antibody. A synergistic effect mediated by the VLA-5 fibronectin receptor complex. J. Exp. Med. 170:1133-1148.

86. McClay, D. R., and C. A. Ettensohn. 1987. Cell adhesion in morphogenesis. Annu. Rev. Cell Biol. 3:319-345.

87. McDonald, J. A. 1989. Receptors for extracellular matrix components. Am. J. Physiol. 257:L331-L337.

88. Menko, A. S., and D. Boettiger. 1987. Occupation of the extracellular matrix receptor, integrin, is a control point for myogenic differentiation. Cell. 51:51-57.

89. Miyauchi, A., J. Alvarez, E. M. Greenfield, A. Teti, M. Grano, S. Colucci, A. Zambonin-Zallone, F. P. Ross, S. L. Teitelbaum, D. Cheresh, and K. A. Hruska. 1991. Recognition of osteopontin and related peptides by an alphav/beta 3 integrin stimulates immediate cel signals in osteoclasts. J. Biol. Chem. 266:20369-20374.

90. Moyle, M., M. A. Napier, and J. W. McLean. 1991. Cloning and expression of a divergent integrin subunit $\beta 8$. J. Biol. Chem. 266:1965019658.

91. Mukaida, N., Y. Mahe, and K. Matsushima. 1990. Cooperative interaction of nuclear factor-kB- and cis-regulatory enhancer binding proteinlike factor binding elements in activating the interleukin- 8 gene by proinflammatory cytokines. $J$, Biol. Chem. 265:21128-21133.

92. Nathan, C., and E. Sanchez. 1990. Tumor necrosis factor and CD11 CD18 $\left(b_{2}\right)$ integrins act synergistically to lower cAMP in human neutrophils. J. Cell Biol. 111:2171-2181.

93. Nathan, C., S. Srimal, C. Farber, E. Sanchez, L. Kabbash, A. Asch, J. Gailit, and S. D. Wright. 1989. Cytokine-induced respiratory burst of human neutrophils: dependence on extracellular matrix proteins and CD11/CD18 integrins. J. Cell Biol. 109:1341-1349.

94. Neugebauer, K. M., and L. F. Reichardt. 1991. Cell surface regulation of betal integrin activity on developing retinal neurons. Nature (Lond.). 350:68-71,

95. Ng-Sikorski, J., R. Andersson, M. Patarroyo, and T. Andersson. 1991. Calcium signaling capacity of the CD11b/CD18 integrin on human neutrophils. Exp. Cell Res. 195:504-508.

96. Nishibe, S., M. I. Wahl, S. M. Hernandez-Sotomayor, N. K. Tonks, S. G. Rhee, and G. Carpenter, 1990. Increase of the catalytic activity of phospholipase C-gammal by tyrosine phosphorylation. Science (Wash. DC). 250:1253-1256.

97. Nojima, Y., M. J. Humphries, A. P. Mould, A. Komoriya, K. M. Yarnada, S. F. Schlossman, and C. Morimoto. 1990. VLA-4 mediates CD3-dependent CD4 + T cell activation via the CS1 alternatively spliced domain of fibronectin. J. Exp. Med. 172:1185-1192.

98. Opipari, A. W. Jr., C. D. Laherty, A. Krikas, and V. M. Dixit. 1992 The A20 zinc-finger protein induced by TNF-a and viruses inhibits programmed cell death. FASEB (Fed. Am. Soc. Exp. Biol.) J. 6:A1780.

98a. O'Rourke, A. M., and M. F. Mescher. 1992. Cytotoxic T-lymphocyte activation involves a cascade of signaling and adhesion events. Nature (Lond.). 358:253-256.

99. Osborn, L. 1990. Leukocyte adhesion to endothelium in infiammation. Cell. $62: 3-6$

100. Otey, C. A., F. M. Pavalko, and K. Burridge. 1990. An interaction between a-actinin and the bl integrin subunit in vitro. $J$. Cell Biol. 111 : $721-729$.

101. Parsons, J. T, and M. J. Weber. 1989. Genetics of src; structure and functional organization of a protein tyrosine kinase. Curr. Top. Microbiol. Immunol. 147:79-127.

102. Deleted in proof.

103. Peters, C. W. B., U. Kruse, R. Pollwein, K..H. Grzeschik, and A. E Sippel. 1989. The human lysozyme gene. Eur. J. Biochem. 182:507516.

104. Phillips, D. R., I. F. Charo, L. V. Parise, and L. A. Fitzgerald. 1988. The platelet membrane glycoprotein IIb-IIIa complex. Blood. 71:831843.

105. Reid, L. M. 1990. Stem cell biology, hormone/matrix synergies and liver differentiation. Curr. Opin. Cell Biol. 2:121-130. 
106. Roberts, W. M., L. H. Shapiro, R. A. Ashmun, and A. T. Look. 1992. Transcription of the human colony-stimulating factor-1 receptor gene is regulated by separate tissue-specific promoters. Blood. 79:586-593.

107. Ruoslahti, E. 1991. Integrins. J. Cin. Invest. 87:1-5.

108. Samelson, L. E., A. F. Philips, E. T. Luong, and R. D. Klausner. 1990. Association of the fyn protein-tyrosine kinase with the T-cell antigen receptor. Proc. Nati. Acad. Sci. USA. 87:4358-4362.

109. Sanes, J. R. 1989. Extracellular matrix molecules that influence neural development. Annu. Rev. Neurosci. 12:491-516.

110. Schaller, M. D., C. A. Borgman, B. S. Cobb, R. R. Vines, A. B. Reynolds, and J. T. Parsons. 1992 . pp125 FAK, a structurally unique protein tyrosine kinase associated with focal adhesions. Proc. Natl. Acad. Sci. USA. In press.

111. Schmidhauser, C., M. J. Bissell, C. A. Myers, and G. F. Casperson. 1990. Extracellular matrix and hormones transcriptionally regulate bovine b-casein $5^{x}$ sequences in stably transfected mouse mammary cells. Proc. Natl. Acad. Sci. USA. 87:9118-9122.

112. Schreck, R., P. Rieber, and P. A. Baeuerle. 1991. Reactive oxygen intermediates as apparently widely used second messengers in the activation of the NF-kB transcription factor and HIV-1. EMBO (Eur. Mol. Biol. Organ.) $J, 10: 2247-2258$.

113. Schwartz, M. A., C. Lechene, and D. E. Ingber, 1991. Insoiuble fibronectin activates the $\mathrm{Na} / \mathrm{H}$ antiporter by clustering and immobilizing integrin alpha5/beta1, independent of cell shape. Proc. Natl. Acad. Sci. USA. 88:7849-7853.

114. Schwartz, M. A., D. E. Ingber, M. Lawrence, T. A. Springer, and C. Lechene. 1991. Multiple integrins share the ability to induce elevation of intracellular pH. Exp. Cell Res. 195:533-535.

115. Seftor, R. E. B., E. A. Seftor, K. R. Gehlsen, W. G. Stetler-Stevenson, P. D. Brown, E. Ruoslahti, and M. J. C. Hendrix. 1992. Role of the alphav/beta 3 integrin in human melanoma cell invasion. Proc. Natl. Acad. Sci. USA. 89:1557-1561.

116. Shakhov, A. N., M. A. Collart, P. Vassalli, S. A. Nedospasov, and C. V. Jongeneel. 1990. kB-type enhancers are involved in lipopolysaccharide-mediated transcriptional activation of the tumor necrosis factor a gene in primary macrophages. $J$. Exp. Med. 171:35-47.

117. Shappell, S. B., C. Toman, D. C. Anderson, A. A. Taylor, M. L. Entman, and C. W. Smith. 1990. Mac-1 (CDI1b/CD18) mediates adherence-dependent hydrogen peroxide production by human and carine neutrophils. I. Immunol. 144:2702-2711.

118. Shaw, R. J., D. E. Doherty, A. G. Ritter, S. H. Benedict, and R. A. F Clark. 1990. Adherence-dependent increase in human monocyte PDGF(B) mRNA is associated with increases in $c-f o s, c$-jun, and EFR2 mRNA. I. Cell Biol. 111:2139-2148.

119. Shimizu, Y., G. A. Van Seventer, K. J. Horgan, and S, Shaw. 1990. Costimulation of proliferative responses of resting $\mathrm{CD} 4+\mathrm{T}$ cells by interaction of VLA4 and VLAS with fibronectin or VLA6 with laminin. J. Immunol. 145:59-67.

120. Shirakawa, F, and S. Mizel. 1989. In vitro activation and nuclear translocation of NF-kB catalyzed by cAMP-dependent protein kinase and protein kinase C. Mol. Cell. Biol. 9:2424-2430.

121. Siu, G., A. L. Wurster, J. S. Lipsick, and S. M. Hedrick. 1992. Expression of the CD4 gene requires a Myb transcription factor. Mol. Cell. Biol. 12:1592-1604.

122. Slupsky, J. R., J, G. Sechafer, S. C. Tang, A. Masellis-Smith, and A. R. E. Shaw 1989 . Evidence that monoclonal antibodies against CD9 antigen induce specific association between $\mathrm{CD} 9$ and the platelet glycoprotein IIb/IIIa complex. J. Biol. Chem. 264:12289-12293.

123. Sporn, S. A., D. F. Eirman, C. E. Johnson, J. Morris, G. Martin, M. Ladner, and S. Haskill. 1990. Monocyte adherence results in selective induction of novel genes sharing homology with mediators of inflammation and tissue repair. J. Immunol. 144:4434-4441.

124. Streuli, C. H., and M. J. Bissell. 1990. Expression of extracellular matrix components is requlated by substratum. $J$. Cell Biol. 110:1405-1415

125. Sung, S.-S. J., J. A. Walters, J. Hudson, and J. M. Gimble. 1991. Tumor necrosis factor-a mRNA accumulation in human myelomonocytic cell lines. J. Immunol. 147:2047-2054.

126. Takada, Y., E. Murphy, P. Pil, C. Chen, M. H. Ginsberg, and M. E Hemler. 1991. Molecular cloning and expression of the cDNA for alpha3 subunit of human alpha3/betal (VLA3) an integrin receptor for fibronectin laminin and collagen. I. Cell Biol 115:257-266.

127. Takada, Y., M. J. Elices, C. Crouse, and M. E. Hemler. 1989. Primary structure of the alpha4 subunit of VLA4; homology to other integrins and a possible cell-cell adhesion function. EMBO (Eur. Mol. Biol. Organ.) J. 8:1361-1368.

128. Tamura, R. N., H. M. Cooper, G. Collo, and V. Quaranta. 1991. Cell type specific integrin variants with alternative alpha chain cytoplasmic domains. Proc. Nath Acad. Sci. USA. 88:10183-10187.

129. Thomas, G. 1992. MAP kinase by any other name smells as sweet. Cell. $68: 3-6$.

130. Thorens, B., I.J. Mermod, and P. V8ssalli. 1987. Phagocytosis and inflammatory stimuli induce GM-CSF mRNA in macrophages through posttranscriptional regulation. Cell. 48:671-679.

131. Ullich, A, and J. Schlessinger. 1990 . Signal transduction by receptors with tyrosine kinase activity. Cell. 61:203-212.

132. Utsumi, K, M. Sawada, S. Narumiya, J. Nagamine, T. Sakata, S. Iwagami, Y. Kita, H. Teraoka, H. Hirano, M. Ogata, T. Hamaoka, and H. Fujiwara, 1991 , Adhesion of immanure thymocytes to thymic stromal cells through fibronectin molecules and its significance for the induction of thymocyte differentiation. Proc. Natl. Acad. Sci. USA. 88:56855689 .

133. van Seventer, G. A., Y. Shimizu, and S. Shaw. 1991. Roles of multiple accessory molecules in T-cell activation. Curr. Opin. Immunol. 3:294303.

134. Veillette, A., M. A. Bookman, E. M. Horak, and J. B. Bolen. 1988. The CD4 and CD8 $T$ cell surface antigens are associated with the internal membrane tyrosine-protein kinase p56Ick. Cell. 55:301-308.

135. Volk, T., L. I. Fessler, and J. H. Fessler. 1990. A role for integrin in the formation of sarcomeric cytoarchitecture. Cell. 63:525-536.

136. Vukicevic, S., F. P. Luyten, H. K. Kleinman, and A. H. Reddi. 1990. Differentiation of canalicular cell processes in bone cells by basement membrane matrix components: regulation by discrete domains of laminin. Cell. 63:437-445.

137. Werb, Z., P. M. Tremble, O. Behrendtsen, E. Crowley, and C. H. Damsky. 1989. Signal transduction through the fibronectin receptor induces collagenase and stromelysin gene expression. J. Cell Biol. 109: $877-889$.

138. Wood, K. W., C. Sarnecki, T. M. Roberts, and J. Blenis, 1992. Ras mediates nerve growth factor receptor modulation of three signal-transducing protein kinases: MAP kinase, Raf-1, and RSK. Cell. 68:1041-1050.

139. Deleted in proof.

140. Yamada, A., T. Nikaido, Y. Nojima, S. F. Schlossman, and C. Morimoto. 1991. Activation of human CD4 T lymphocytes: Interaction of fibronectin with VLA-5 receptor on CD4 cells induces the AP-I transcription factor. J. Immunol. 146:53-56.

141. Yamada, H., S. Iwase, M. Mohri, and D. Kufe 1991. Involvement of a nuclear factor-kB-like protein in induction of the macrophage colonystimulating factor gene by tumor necrosis factor. Blood. 78:1988-1995.

142. Yamanashi, Y., T. Kakiuchi, J. Mizuguchi, T. Yamamoto, and K Toyoshima. 1991. Association of B cell antigen receptor with protein tyrosine kinase Lyn. Science (Lond.). 251:192-195.

143. Yurochko, A. D., D. Y. Liu, D. Eierman, and S. Haskill. 1992. Integrins as a primary signal transcuction molecule regulating monocyte immediate-early gene induction. Proc. Notl. Acad. Sci. USA. 89:90349038.

144. Zhang, J., M. J. Fry, M. D. Waterield, S. Jaken, L. Liao, J. E. B. Fox, and S. E. Rittenhouse. 1992. Activated phosphoinositide-3-kinase associates with membrane skeleton in thrombin exposed platelets. J. Biol. Chem. 267:4686-4692.

145. Zusman, S., R. S. Patel-King, C. French-Constant, and R. O. Hynes. 1990. Requirements for integrins during Drosophila development. $D e$ velopment (Camb.). 108:391-402. 